\title{
Health-related physical fitness in men and women aged 17-26 years
}

\section{Aptidão física relacionada à saúde em homens e mulheres de 17-26 anos}

\author{
Alex Silva Ribeiro ${ }^{1,2}$ \\ Danilo Rodrigues Pereira da Silva ${ }^{1,2}$ \\ Ferdinando Oliveira Carvalho ${ }^{1,3}$ \\ Durcelina Schiavoni $\mathrm{i}^{1,4}$ \\ Bruno Cesar Silva de Jesus ${ }^{1}$ \\ Edilson Serpeloni Cyrino ${ }^{1,2}$
}

Rev Bras Ativ Fis Saúde p. 197-204

DOI:

http://dx.doi.org/10.12820/rbafs.v.18n2p197

1Grupo de Estudo e Pesquisa em

Metabolismo, Nutrição e Exercício. Centro de Educação Física e Esporte. Universidade Estadual de Londrina. Londrina, PR, Brasil.

2Programa de Pós-Graduação Associado em Educação Física - UEM/UEL.

3Universidade Federal do Vale do São Francisco (UNIVASF). Petrolina, PE, Brasil.

4Universidade Paranaense (UNIPAR).

Francisco Beltrão, PR, Brasil.

\begin{abstract}
This study aimed to evaluate health-related physical fitness in male and female undergraduate students of Physical Education and Sports. Two hundred and fifty-seven 257 volunteer students aged 17 to 26 years (132 females and 125 males) underwent an antrhopometric assessment and motor fitness tests including sit-and-reach test (SRT), a modified abdominal fitness test (ABDT), and 12-minute run-walk test (12MRW). The results showed significant gender differences $(p<0.05)$ in the $12 \mathrm{MRW}$ (males $=2,479 \pm 333$ vs. females $=1,899 \pm 230 \mathrm{~m}$ ), ABDT (males $=45 \pm 9$ vs. females $=34 \pm 10$ repetitions) and SRT (males $=31 \pm 8$ vs. females $=33 \pm$ $7 \mathrm{~cm}$ ). A higher proportion of males met the criteria in the $12 \mathrm{MRW}$ (males $=62 \% \mathrm{vs}$. females $=11 \%$ ) and ABDT (males $=95 \%$ vs. females $=85 \%$ ). Most subjects met the criteria in two or three tests (92\% males and $85 \%$ females). These findings suggest that undergraduate students of Physical Education and Sports, either males or females, tend to have higher levels of abdominal strength and endurance and flexibility despite a low level of cardiorespiratory fitness.
\end{abstract}

\section{Keywords}

Physical fitness; University students; Health.

\section{Resumo}

O objetivo do presente estudo foi avaliar a aptidão física relacionada à saúde de homens e mulheres, estudantes do curso de Educação Física/Esporte. Para tanto, 257 voluntários do curso de Educação Física/Esporte de ambos os sexos (132 mulheres e 125 homens), de 17 a 26 anos, foram submetidos a medidas antropométricas e os seguintes testes motores: sentar e alcançar (SA), abdominal modificado (ABD) e corrida/caminhada de 12 minutos $(12 \mathrm{~min})$. Os resultados demonstraram diferenças significantes $(p<0,05)$ entre homens e mulheres para o teste de $12 \mathrm{~min}$ (homens $=2479 \pm 333$ vs. mulheres $=1899 \pm 230 \mathrm{~m}$ ), ABD (homens $=45 \pm 9$ vs. mulheres $=34 \pm 10$ repetiçóes) e $S A$ (homens $=31 \pm$ 8 vs. mulheres $=33 \pm 7 \mathrm{~cm}$ ). Os homens apresentaram uma maior taxa de atendimento aos critérios estabelecidos no teste de $12 \mathrm{~min}$ (homens $=62 \%$ vs. mulheres $=11 \% ; p<0,05)$ e ABD (homens $=95 \%$ vs. mulheres $=85 \% ; p<0,05$ ), sem diferença significante entre os sexos no $S A$ (homens $=93 \%$ vs. mulheres = 96\%; $p>0,05)$. A grande maioria dos sujeitos investigados atenderam os critérios estabelecidos para dois ou três testes analisados (92\% dos homens e $85 \%$ das mulheres). Assim, os resultados sugerem que estudantes do curso de graduação em Educação Física/Esporte tendem a apresentar elevados níveis de resistência de força abdominal e flexibilidade, independente do sexo, embora grande parte deles apresente niveis de aptidão cardiorrespiratória insatisfatórios.

\section{Palavras-chave}

Aptidão física; Universitários; Saúde. 


\section{INTRODUCTION}

Physical fitness is a term used to designate a set of individual biological attributes that can be improved or worsened depending on lifestyle, advancing age and general health. Physical fitness of an individual or a group, sample or population has been historically assessed through scores obtained on specific motor tests designed to assess several related-health components and physical fitness abilities required for athletic performance.

Several studies have been developed in recent years to assess physical fitness, especially in children and adolescents, ${ }^{1-6}$ the elderly, ${ }^{7,8}$ athletes ${ }^{9-13}$ and individuals with medical conditions. ${ }^{14}$ However, only a small number of studies has investigated physical fitness in young adults. ${ }^{15-17}$ It is noteworthy since many investigations focusing on different kinds of training programs often include in their samples young adults largely recruited from colleges and who are mostly undergraduate students of Physical Education and Sports.

Bearing in mind specific course requirements and characteristics of physical education and sports, normally students enrolled in these courses are believed to have high levels of physical fitness and to be more physically fit than most college students from other courses. If this assumption is actually valid, the analysis of the impact of different training strategies on samples of undergraduate students of Physical Education and Sports can be skewed if it is not controlled for their baseline fitness levels.

The knowledge of physical fitness levels of undergraduate students of physical education and sports can help decision-making in the selection of participants in research projects, especially in longitudinal studies. Thus, this study aimed to evaluate fitness levels of both female and male undergraduate students of Physical Education and Sports through a criterion-referenced assessment. In this study, we hypothesized that most students investigated meet the criteria for health-related physical fitness, that male subjects outperform (in absolute terms) in motor fitness tests their female peers, and that there is no gender differences in meeting the criteria established for the motor fitness tests used.

\section{METHODS}

\section{Subjects}

Of a total of 670 undergraduate students in Physical Education and Sports recruited at a public university in the city of Londrina, state of Paraná, southern Brazil, 257 agreed to voluntarily participate in this study. The sample comprised 132 females and 125 males aged 17 to 26 years. Subjects were recruited through poster board advertisements, classroom briefing sessions, and email invitations sent to a specific directory of email addresses by the researchers. The inclusion criteria were having no signs or symptoms of any disease and no orthopedic issues that could prevent testing. All students were previously informed about the study procedures and risks and those who agreed to participate signed a free informed consent. The study was conducted in accordance with the guidelines for research involving human subjects (Resolution 196/96 of the Brazilian Ministry of Health National Health Council) and approved by the university's research ethics committee (protocol number 028/2012). 


\section{Anthropometric assessment}

Body mass was measured to the nearest $0.1 \mathrm{~kg}$ using an electronic platform scale (model PS 180, Urano) and height was measured to the nearest $0.1 \mathrm{~cm}$ using a wooden stadiometer following the procedures as described in the literature. ${ }^{18}$ All weight and height measures were taken barefoot. The body mass index (BMI) was calculated by dividing body weight in kilograms $(\mathrm{kg})$ by height in meters $(\mathrm{m})$.

\section{Health-related physical fitness}

Health-related physical fitness components were assessed using three different motor fitness tests in the following sequence: sit-and-reach test (SRT), a modified abdominal fitness test (ABDT) and 12-minute run-walk test (12MRW). The SRT assessed the flexibility of hip, lower back and hamstring muscles. A standard box was used to position the subjects for testing and a measuring line was centrally fixed on the box to measure and record the distance reached by the hands. Subjects were positioned sitting on the floor with legs fully stretched out straight ahead, feet shoulder-width apart with the soles of the feet placed flat against the box. With the hands on top of each other and knees fully pressed flat to the floor, they were asked to slowly bend forward their trunk without bouncing and reach forward along the measuring line as far as possible, holding that position for at least two seconds while the distance was recorded. The fingertips were kept parallel so that both hands would be aligned. Each subject had three attempts and the highest score of the three attempts was recorded (in centimeters).

The ABDT measured abdominal and upper limb strength. Subjects were in a supine position on a mat with knees bent at a right angle, feet on the ground-a co-evaluator held the feet in place during the test. With the arms crossed over the chest, each hand grasping the opposite shoulder, they were asked to move their trunk forward lifting their lower back off the surface of the mat till the elbows reached the thighs and then return to the starting position and repeat this movement for 60s. An evaluator recorded the number of properly performed repetitions. The total number of correct repetitions completed in one minute was recorded.

The 12MRW measured cardiorespiratory fitness. Subjects were instructed to run or walk on a standard $400-\mathrm{m}$ running track as far as possible in a 12-minute period. They were asked to walk, trot or run keeping a relatively constant pace. At the end of the 12-minute period, subjects were instructed to keep walking for recovery. The distance covered was recorded as the number of laps accounting for any additional distance covered during the test period. An evaluator measured and recorded the distance covered by each subject.

All tests were administered by previously trained evaluators. Cutoff points were set for SRT and ABDT following Pollock and Wilmore recommendations. ${ }^{19}$ Students scoring $\geq 19 \mathrm{~cm}$ (females and males) in the $\mathrm{SRT}$ and $>33$ repetitions (for males) and $>25$ repetitions (for females) in the ABDT were considered fit. In the $12 \mathrm{MRW}$, the results were assessed based on Cooper proposed fitness criteria, ${ }^{20}$ $>2400 \mathrm{~m}$ for males and $>2200 \mathrm{~m}$ for females. Subjects were divided into two categories, those who met and those who did not meet the criteria. All subjects reported being familiar with these tests from their physical education classes in elementary and/or middle school. In addition, they were advised to have a light meal two hours prior to testing and to avoid strenuous physical activity in the 24 hours preceding the tests. 


\section{Statistical analysis}

The Kolmogorov-Smirnov test was performed to assess data distribution. For normally distributed variables, comparisons between males and females were carried out using the Student's t-test for independent samples. The assumption of normality was not confirmed for the 12MRW and ABDT variables so the Mann-Whitney U test was used for comparisons between males and females. The chi-square test was used to test the association between criteria meeting and gender. The number of criteria met was expressed as relative frequency, and a test for proportions comparison was used to assess behavioral differences between males and females. The level of significance was set at $p<0.05$. Data analysis was conducted using SPSS version 17.0.

\section{RESULTS}

Table 1 shows physical characteristics of subjects according to gender. Significant differences between females and males were found for all variables studied.

Table 1 - Physical characteristics of subjects by gender $(n=257)$.

\begin{tabular}{lccccc}
\hline \multicolumn{5}{c}{ Males $(n=125)$} & \multicolumn{2}{c}{ Females $(\mathrm{n}=132)$} \\
\hline & Mean $\pm \mathrm{SD}$ & $95 \% \mathrm{Cl}$ & Mean $\pm \mathrm{SD}$ & $95 \% \mathrm{Cl}$ & $p$-value \\
\hline Age (years) & $20.4 \pm 2.3$ & $20.0-20.8$ & $19.9 \pm 1.91$ & $19.5-20.1$ & 0.033 \\
\hline Height $(\mathrm{cm})$ & $175.4 \pm 6.8$ & $174.2-176.6$ & $162.5 \pm 6.2$ & $161.4-163.6$ & $<0.001$ \\
\hline BM $(\mathrm{kg})$ & $70.8 \pm 8.7$ & $69.3-72.4$ & $57.6 \pm 7.2$ & $56.3-58.8$ & $<0.001$ \\
\hline BMI $\left(\mathrm{kg} / \mathrm{m}^{2}\right)$ & $23.0 \pm 2.4$ & $22.5-23.4$ & $21.8 \pm 3.0$ & $21.3-22.4$ & 0.001 \\
\hline 12 MRW $(\mathrm{m})$ & $2479 \pm 333$ & $2420-2538$ & $1899 \pm 230$ & $1859-1939$ & $<0.001$ \\
\hline ABDT $(\mathrm{reps})$ & $45 \pm 9$ & $44-47$ & $34 \pm 10$ & $33-36$ & $<0.001$ \\
\hline SRT $(\mathrm{cm})$ & $31.0 \pm 7.8$ & $29.6-32.3$ & $33.0 \pm 7.4$ & $31.7-34.3$ & 0.032 \\
\hline
\end{tabular}

$\mathrm{BM}=$ body mass; $\mathrm{BMI}=$ body mass index $; 12 \mathrm{MRW}=12$-minute run-walk test $\mathrm{ABDT}=$ modified abdominal fitness test; $\mathrm{SRT}=$ sit and reach test; $\mathrm{SD}=$ standard deviation; $\mathrm{Cl}=$ confidence interval; reps $=$ repetitions.

Figure 1 shows the proportion of males and females who met the criteria for each test. Significant differences were found in the 12MRW $(p<0.001)$ and ABDT $(p \leq 0.05)$; a higher proportion of males than females met the criteria. In the SRT, there were no significant association between gender and criteria meeting $(p=0.228)$.

Figure 2 shows the proportion of subjects who had met the criteria by gender. In the entire sample studied, the proportion of subjects who did not meet any criteria, met the criteria in one, two and three fitness tests was $0.8 \%, 10.1 \%, 58.0 \%$ and $31.1 \%$, respectively. A gender comparison showed significant differences regarding meeting the criteria in two $(38.4 \%$ males vs. $76.5 \%$ females, $p<0.05)$ and three tests $(55.2 \%$ males vs. $8.3 \%$ females, $p<0.01)$. There was no difference between those who did not meet any criteria $(0.0 \%$ males vs. $1.5 \%$ females, $p=$ $0.89)$ and those who met the criteria in one test (6.4\% males vs. $13.6 \%$ females, $p=0.96)$. 

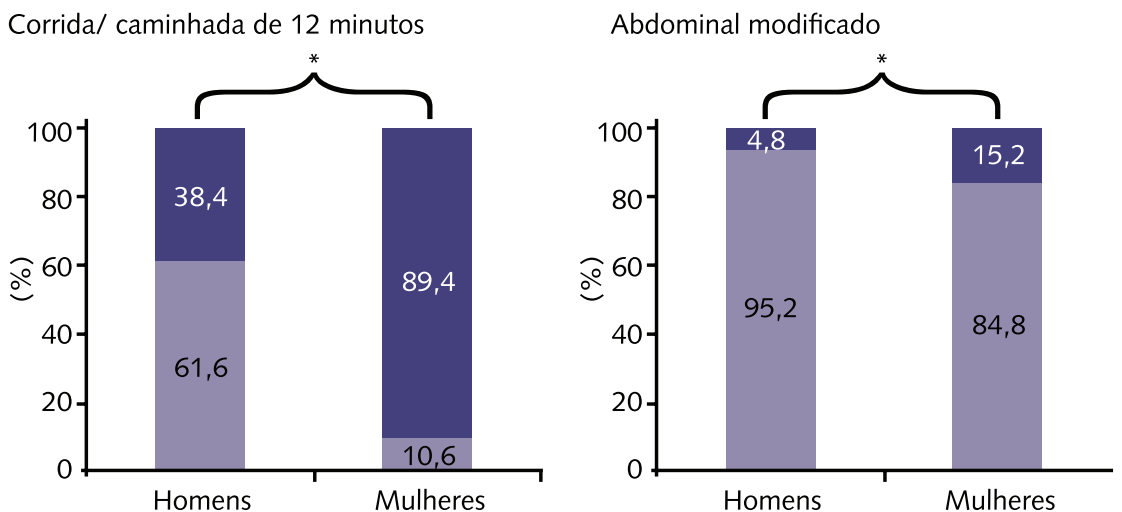

Sentar e alcançar

Figure 1 - Proportion of subjects (\%) who met the criteria according to gender (males $=125$; females $=132$ ) in each test. ${ }^{*} \mathrm{p}<0.05$ between males and females.

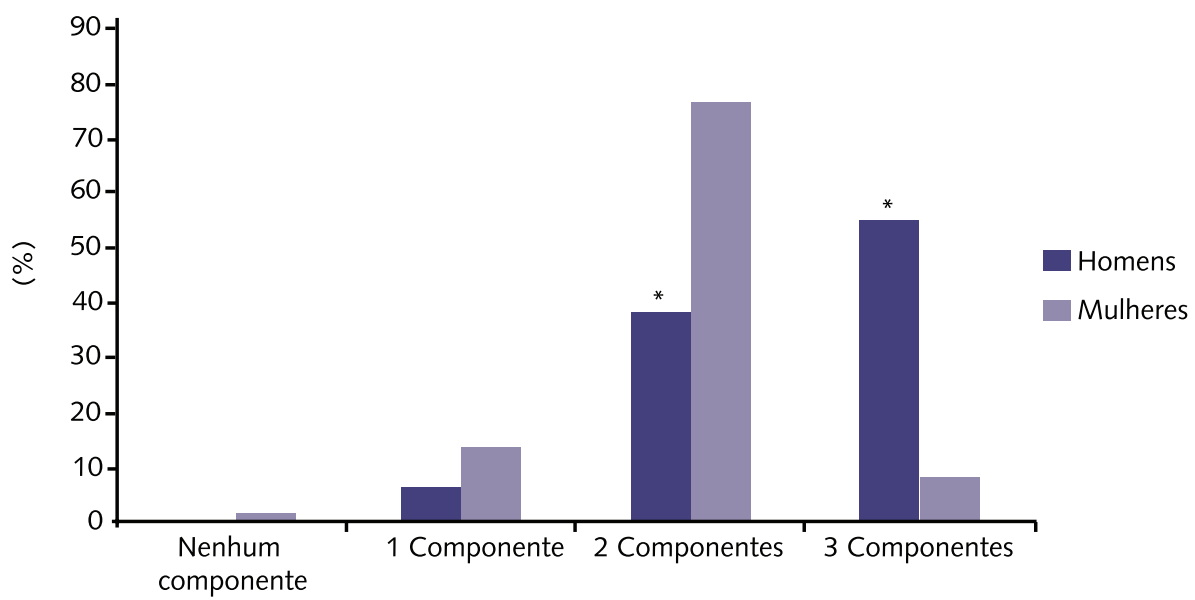

Figure 2 - Proportion of subjects (\%) who meet the criteria for the physical fitness components according to gender (males $=125$; females $=132$ ). ${ }^{*} p<0.05$ vs. females.

\section{DISCUSSION}

The main findings of the present study were as follows: most subjects met the criteria in two or three tests (92\% males and $85 \%$ females); a higher proportion of subjects did not meet the criteria in the cardiorespiratory fitness test (38\% males and $89 \%$ females); undergraduate students of Physical Education and Sports, either females or males, tend to have tend to have higher levels of abdominal strength and endurance and flexibility.

The analysis of individual indicators of physical fitness showed males performed better in the motor tests ABDT and 12MRW whereas females showed better results in the SRT test, corroborating previously published data. ${ }^{15-17} \mathrm{In}$ addition, significantly higher proportion of males met the criteria for cardiorespiratory fitness confirming previous reports. ${ }^{15,16}$ However, it should be noted the proportions of both female and male subjects meeting the criteria for cardiorespiratory fitness were the lowest. This is a concerning finding since the literature shows a strong correlation between adequate cardiorespiratory fitness and good body function. ${ }^{21-23}$

With regard to muscle strength and endurance, although this study found a higher proportion of males meeting the established criteria, our results are consistent with other studies. ${ }^{15,16}$ However, it is noteworthy the large proportion of 
both female and male subjects meeting the criteria in this test. The differences between males and females in the ABDT may be partly explained by different levels of physical activity as reported in previous studies, ${ }^{24,25}$ and greater engagement of males in high-intensity activities than females ${ }^{26}$ - low-intensity activity is associated with lower levels of muscular fitness. ${ }^{27}$ But this information was not available in the present study to confirm these assumptions. The ABDT was the test of choice to assess strength and endurance for its association with the prevention of postural problems and musculoskeletal injuries and potential for predicting mortality risk. ${ }^{28,29}$

The results of the SRT showed good flexibility among both female and male subjects, but they are not corroborated by other studies ${ }^{15,16}$ that found a large proportion of subjects with "low levels of flexibility." These inconsistent results may be due to different cutoff points used as fitness criteria across studies. The SRT does not completely reflect the overall flexibility in different joints and joint movements but it is the most widely used test to assess flexibility of the lower back and posterior thighs, which has a major role in several daily activities and in preventing lower back pain. ${ }^{28}$

The analysis of the three physical fitness components used in this study indicated that a greater number of males than females met the established criteria. These findings do not support our initial assumption that there are no sexual differences in the physical fitness components investigated in our study, especially among undergraduate students of Physical Education and Sports.

Although the literature suggests students of physical education are more active than those in other areas of knowledge, ${ }^{30}$ yet their level of physical fitness-particularly cardiorespiratory fitness-is largely low. Researchers should take into consideration this finding especially when selecting subjects for intervention studies based on exercise training programs including the variables analyzed here. For instance, subjects in studies of resistance flexibility and strength may have high levels of neuromuscular fitness at baseline, which may negatively affect the magnitude of training-induced changes. In contrast, in studies of cardiorespiratory fitness interventions, training-induced changes may be maximized by subjects' low level of cardiorespiratory fitness at baseline.

Thus, an individual's baseline fitness level is a major factor in both acute and chronic investigations of physiological responses to different types of exercise training. Since undergraduate students of Physical Education and Sports are often included in studies designed to assess different biological aspects related to physical activity, it is important to take into consideration baseline fitness levels of subjects to ensure more reliable results.

Despite its major results, several limitations to this study need to be acknowledged. Motor tests do not provide a direct measure of different components of physical fitness; however, the tests performed are widely used, valid, reproducible tools. Furthermore, measurement reproducibility was not assessed in this study, but all subjects reported being familiar with the tests performed, which may in part have minimized potential bias related to being unfamiliar with the tests. Finally, the subjects' level of physical activity was not controlled for, which could have helped explain the differences found between males and females.

The present study was based on internationally accepted criteria which allow to analyzing whether the results have a relationship with adverse health-related outcomes, considering potential gender differences in motor performance. 


\section{CONCLUSIONS}

The study results suggest that undergraduate students of Physical Education and Sports, either females or males, tend to have high levels of abdominal strength and endurance and flexibility. However, most male and female students showed low levels of cardiorespiratory fitness, which increases the risk of developing several conditions, especially chronic degenerative diseases. Finally, a comparison of the proportions of subjects meeting the established criteria for fitness confirmed gender differences in the ABDT and 12MRW, with a greater proportion among males.

\section{Acknowledgments}

The authors thank the National Council for Scientific and Technological Development $(\mathrm{CNPq})$ for its support through a research grant to ESC and the Brazilian Federal Agency for Support and Evaluation of Graduate Education (CAPES) for its supported through a Master's degree grant to ASR.

\section{Author contributions}

Edilson Serpeloni Cyrino, Ferdinando Oliveira Carvalho and Durcelina Schiavoni contributed to the study design and data collection. Alex Silva Ribeiro, Danilo Rodrigues Pereira da Silva and Bruno Cesar Silva de Jesus identified and reviewed studies for the discussion and performed data analysis and interpretation. All authors contributed in the manuscript drafting and final review.

\section{REFERENCES}

1. Dórea $\mathrm{V}$, Ronque ERV, Cyrino ES, et al. Aptidão física relacionada à saúde em escolares de Jequié, BA, Brasil. Rev Bras Med Esporte 2008;14:494-499.

2. Okano AH, Altimari LR, Dodero SR, et al. Comparação entre o desempenho motor de crianças de diferentes sexos e grupos étnicos. Rev Bras Ciên Mov 2001;9:39-44.

3. Petroski EL, Silva AF, Rodrigues AB, Pelegrini A. Aptidão física relacionada a saúde em adolescentes brasileiros residentes em áreas de médio/baixo índice de desenvolvimento humano. Rev Salud Pública 2011;13:219-228.

4. Ronque ERV, Cyrino ES, Dórea VR, et al. Diagnóstico da aptidão física em escolares de alto nível socioeconômico: avaliação referenciada por critérios de saúde. Rev Bras Med Esporte 2007;13:71-76.

5. Santos MMA, Ribeiro SML, Pellegrini AM, Rocha PRH, Hiraga CY. Crianças com dificuldades motoras apresentam baixos níveis de aptidão física? Motriz 2012;18:748-756.

6. Serassuelo Junior $\mathrm{H}$, Rodrigues $\mathrm{AR}$, Cyrino ES, et al. Aptidão física relacionada à saúde em escolares de baixo nível socioeconômico do município de Cambé/PR. Rev Educ Fís/UEM 2005;16:7-13.

7. Faccari VLK, Piccoli JCJ, Queveda DMD. Aptidão física relacionada à saúde de idosas da região do Vale do Sinos, RS: um estudo ex post-facto. Rev Bras Geriatr Gerontol 2012;15:651-660.

8. Teixeira DC, Hernandes NA, Probst VS, et al. Profile of physical activity in daily life in physically independent elderly men and women. Rev Bras Educ Fis Esporte 2012;26:645-655.

9. Avelar A, Santos KM, Cyrino ES, et al. Perfil antropométrico e de desempenho motor de atletas paranaenses de futsal de elite. Rev Bras Cineantropom Desempenho Humano 2008;10:76-80.

10. Canhadas IL, Silva RLP, Chavez CR, Portes LA. Anthropometric and physical fitness characteristics of young male soccer players. Rev Bras Cineantropom Desempenho Humano 2010;12:239-245.

11. Cyrino ES, Altimari LR, Okano AH, et al. Efeitos do treinamento de futsal sobre a composição corporal e o desempenho motor de jovens atletas. Rev Bras Ciên Mov 2002;10:41-46.

12. Gomes SA, Satero RC, Giavoni A. Avaliação da composição corporal e dos níveis de aptidão física de atletas de futsal classificados segundo a tipologia dos esquemas e de gênero. Rev Bras 
Med Esporte 2011;17:156-160.

13. Ritti-Dias RM, Carvalho FO, Souza CF, et al. Características antropométricas e de desempenho motor de atletas de futsal em diferentes categorias. Rev Bras Cineantropom Desempenho Humano 2007;9:297-302.

14. Anjos DMC, Araújo IL, Barros BM, Pereira DAG, Pereira DS. Avaliação da capacidade funcional em idosos diabéticos. Fisioter Pesq 2012;19:73-78.

15. Corseuil MW, Petroski EL. Baixos níveis de aptidão física relacionada à saúde em universitários. Rev Bras Educ Fis Esporte 2010;24:49-54.

16. Loch MR, Konrad LM, Santos PD, Nahas MV. Perfil da aptidão física relacionada á saúde de universitários da educação física curricular. Rev Bras Cineantropom Desempenho Humano 2006;8:96-104.

17. Dias DF, Reis ICB, Reis DA, et al. Comparação da aptidão física relacionada a saúde de adultos de diferentes faixas etárias. Rev Bras Cineantropom Desempenho Humano 2008;10:123-128.

18. Gordon CC, Chumlea WC, Roche AF. Stature, recumbent length, and weight In: Lohman TG, Roche AF, Martorel R, editors. Anthropometric standardizing reference manual. Champaign: Human Kinetics Books; 1988. p. 3-8.

19. Pollock ML, Wilmore JH. Exercício na saúde e na doença: avaliação e prescrição para a prevenção e reabilitação. São Paulo: Medsi; 1993.

20. Cooper KH. The aerobics program for total well-being. Toronto, New York, London, Sydney, Aucland: Bantam Books; 1982.

21. Garber CE, Blissmer B, Deschenes MR, et al. American College of Sports Medicine position stand. Quantity and quality of exercise for developing and maintaining cardiorespiratory, musculoskeletal, and neuromotor fitness in apparently healthy adults: guidance for prescribing exercise. Med Sci Sports Exerc 2011;43:1334-1359.

22. Farrell SW, Fitzgerald SJ, McAuley PA, Barlow CE. Cardiorespiratory fitness, adiposity, and all-cause mortality in women. Med Sci Sports Exerc 2010;42:2006-2012.

23. Fernandez RA, Codogno JS, Campos EZ, et al. Consumo máximo de oxigênio e fatores de risco cardiovascular em adultos jovens. Revista Brasileira de Atividade Física e Saúde 2009;14:96103.

24. Guedes DP, Santos CA, Lopes CC. Estágios de mudanças de comportamento e prática habitual de atividade física em universitários. Rev Bras Cineantropom Desempenho Humano 2006;8:5-15.

25. Silva FSF, Bergamaschine R, Rosa M, et al. Avaliação do nível de atividade física de estudantes de graduação das áreas da saúde. Rev Bras Med Esporte 2007;13:39-42.

26. Anjos LA, Ferreira BCM, Vasconcellos MTL, Wahrlich V. Gasto energético em adultos do município de Niterói, Rio de Janeiro: resultados da pesquisa de nutrição, atividade física e saúde - PNAFS. Ciência e Saúde Coletiva 2008;13:1775-1784.

27. Paalanne NP, Korpelainen RI, Taimela SP, et al. Muscular fitness in relation to physical activity and television viewing among young adults. Med Sci Sports Exerc 2009;41:1997-2002.

28. Glaner MF. Importância da aptidão física relacionada à saúde. Rev Bras Cineantropom Desempenho Humano 2003;5:75-85.

29. Katzmarzyk PT, Craig CL. Musculoskeletal fitness and risk of mortality. Med Sci Sports Exerc 2002;34:740-744.

30. Resende MA, Resende RBV, Tavares RS, Santos CRR, Barreto-Filho JAS. Estudo comparativo do perfil pró-aterosclerótico de estudantes de Medicina e de Educação Física. Arq Bras Cardiol 2010;95:21-29. 